\title{
PELATIHAN MEMBUAT KOMPOS DARI LIMBAH PERTANIAN DI SUBAK TELAGA DESA MAS KECAMATAN UBUD
}

\author{
Oleh \\ Ni Made Wiratini, I Ketut Lasia, Siti Maryam, Nyoman Retug \\ Fakultas Matematika dan IPA \\ Universitas Pendidikan Ganesha
}

\begin{abstract}
ABSTRAK
Pelatihan ini bertujuan: mengurangi ketergantungan para petani padi terhadap pupuk urea, mengenalkan pupuk kompos sebagai pengganti pupuk urea, melatih para petani padi membuat kompos dari jerami padi dan kotoran sapi, dan melatih cara menggunakan kompos jerami padi. Subyek pelatihan ini adalah para petani di Subak Telaga Desa Mas Ubud. Sedangkan obyek pelatihan adalah kompos, menyangkut cara pembuatan, cara penggunaan, dan keunggulannya. Untuk mencapai tujuan pelatihan digunakan metode diskusi dan praktek. Hasil pelatihan dianalisis secara deskriptif. Hasil pelatihan menunjukkan bahwa peetani padi di subak telaga desa mas mulai mengurangi penggunaan urea dengan mengganti dengan kompos, dapat membuat kompos jerami dengan menggunakan kotoran sapi, jerami, dan EM4, dan dapat menggunakan kompos padi untuk tanaman padi secara benar.
\end{abstract}

Kata-kata kunci: kompos, limbah pertanian

\begin{abstract}
This training aims to: reduced dependence on rice farmers against urea fertilizer, compost introduced as a replacement for urea fertilizer, train rice farmers to make compost from rice straw and cow dung, and trained how to use rice straw compost. The subjects of the training were farmers in Subak Telaga Mas Village of Ubud. While the object of the training was compost, regarding how to make, how to use, and its superiority. Method of the training was discussed and practiced. Training results were analyzed descriptively. Training results indicate that famers at Subak Telaga Mas Village Of Ubud was started to reduce the use of urea by replacing with compost, straw can be made compost using cow dung and EM4, and rice compost can be used correctly.
\end{abstract}

Key words: compost, agricultural wastes

\section{Pendahuluan}

Indonesia merupakan negara pengimpor beras terbesar di dunia (14\% dari beras yang diperdagangkan di dunia), diikuti Banggladesh (4\%), dan Brazil (3\%). Produksi padi Indonesia 54 juta ton tahun 2006, 57 juta ton tahun 2007. Produksi padi tahun 2007 
lebih kecil dari yang ditargetkan yaitu 60 juta ton. Ketidakberhasilan target tersebut, disebabkan oleh kekurangan pupuk urea dan terjadi kekeringan (Kompas, 2010). Kekurangan pupuk urea menyebabkan unsur hara yang diperlukan oleh padi menjadi berkurang. Untuk itu diperlukan tambahan pupuk untuk menambah kesuburan tanah.

Tambahan pupuk yang diperlukan oleh tanah pertanaian padi dalam bentuk pupuk urea, SP-36, dan KCl masing-masing $110 \mathrm{~kg}$ urea/Ha, $25 \mathrm{~kg}$ SP-36/Ha, dan $60 \mathrm{~kg}$ $\mathrm{KCl} / \mathrm{Ha}$. Tambahan tersebut diperlukan, karena sumbangan hara $\mathrm{N}, \mathrm{P}$, dan $\mathrm{K}$ dari tanah sawah beririgasi mampu mensuplai kebutuhan hara N 60\%, P 80\%, dan K $80 \%$ dari hasil gabah 6 ton/hektar. Besar sumbangan N, P, dan K dari tanah masing-masing 90 kg/Ha, 16 kg/Ha, dan 90 kg/Ha. (Daniel Suryoputro, 2009). Hal tersebut juga terjadi di daerah pertanian padi di Subak Telaga Desa Mas Kecamatan Ubud.

Kebutuhan pupuk urea sangat meningkat dimusim pemupukan, yaitu katika padi berusia 14-20 hari dan 40-50 hari. Ketika musim pemupukan tiba, suplai pupuk urea sering tersendat dan langka di pasaran. Ditengah kelangkaan dan kebutuhan pupuk urea yang mendesak, harga pupuk mencapai Rp.140.000-150.000 per $50 \mathrm{~kg}$ yang seharusya Rp. 70.000-80.000 per 50 kg pada bulan Januari 2012 kata pekaseh Subak Telaga Desa Mas Ubud. Kenaikan harga pupuk urea tidak sebanding dengan kenaikan harga gabah petani. Disamping itu, pemakaian pupuk urea secara terus menerus mengakibatkan tanah menjadi memadat, harga mahal, dan tekstur tanah menjadi rusak.Untuk itu diperlukan alternatif untuk memecahkan kelangkaan dan kekurangan pupuk di Subak Telaga Desa Mas Kecamatan Ubud Kabupaten Gianyar.

Upaya untuk mengatasi kekakurangan dan kelangkaan pupuk pada petani padi di Subak Telaga Desa Mas Kecamatan Ubud adalah dengan mencari sumber lain sebagai pupuk. Sumber tersebut adalah mengganti pupuk urea dengan pupuk kompos. Salah satu bahan yang dapat dijadikan kompos adalah limbah pertanian jerami padi. Menurut Kim and Dale (2004) potensi jerami padi kurang lebih adalah 1.4 kali dari hasil panennya. Data Deptan produktivitas padi secara nasional adalah 48,95 ku/ha dan produksi padi nasional pada tahun 2008 adalah sebesar 57,157 juta ton. Jumlah jerami secara nasional yaitu sebesar 80,02 juta ton (Isroi, 2009). Jumlah jerami yang besar tersebut belum diolah secara maksimal oleh petani padahal jerami banyak mengandung 
unsur hara yang diperlukan oleh tanaman padi. Salah satunya adalah jerami diolah menjadi kompos.

Jerami padi mengasilkan $1 / 2$ ton sampai $2 / 3$ ton kompos setiap 1 ton. Kandungan beberapa unsur hara untuk 1 ton kompos jerami padi adalah : unsur makro Nitrogen $(\mathrm{N})$ 2,11\%, Fosfor (P2O5) 0,64\%, Kalium (K2O) 7,7\%, Kalsium (Ca) 4,2\%, serta unsur mikro Magnesium (Mg) 0,5\%, Cu 20 ppm, Mn 684 ppm dan Zn 144ppm (Sri Suryani, 2009)g. Kompos jerami yang dibuat dengan promi dengan waktu pengomposan 3 minggu memiliki rasio C/N 18,88; C 35,11\%; N 1,86\%; P2O5 0,21\%; K2O 5,35\%; dan Air 55\%. Berdasarkan data tersebut, kompos jerami memiliki kandungan hara setera dengan 41,3kg urea, 5,8 kg SP36, dan $89,17 \mathrm{~kg} \mathrm{KCl}$ per ton kompos atau total $136,27 \mathrm{~kg}$ NPK per ton kompos kering (Isroi, 2009).

Pemakaian kompos memiliki keunggulan, antara lain: menghemat biaya untuk transportasi dan penimbunan limbah, mengurangi volume/ukuran limbah, memiliki nilai jual yang lebih tinggi dari pada bahan asalnya, mengurangi polusi udara karena pembakaran limbah dan pelepasan gas metana dari sampah organik yang membusuk akibat bakteri metanogen di tempat pembuangan sampah, mengurangi kebutuhan lahan untuk penimbunan, meningkatkan kesuburan tanah, memperbaiki struktur dan karakteristik tanah, meningkatkan kapasitas penyerapan air oleh tanah, meningkatkan aktivitas mikroba tanah, meningkatkan kualitas hasil panen (rasa, nilai gizi, dan jumlah panen), menyediakan hormon dan vitamin bagi tanaman, menekan pertumbuhan/serangan penyakit tanaman, meningkatkan retensi/ketersediaan hara di dalam tanah. Berdasarkan uraian di atas pelatihan bertujuan mengurangi ketergantungan para petani padi terhadap pupuk urea, mengenalkan pupuk kompos sebagai pengganti pupuk urea, melatih para petani padi membuat kompos dari jerami padi dan kotoran sapi, dan melatih cara menggunakan kompos jerami padi di Subak Telaga Desa Mas.

Secara alami bahan-bahan organik akan mengalami penguraian di alam dengan bantuan mikroba maupun biota tanah lainnya. Namun proses pengomposan yang terjadi secara alami berlangsung lama dan lambat. Untuk mempercepat proses pengomposan ini telah banyak dikembangkan teknologi-teknologi pengomposan. Baik pengomposan dengan teknologi sederhana, sedang, maupun teknologi tinggi. Pada prinsipnya pengembangan teknologi pengomposan didasarkan pada proses penguraian bahan 
organik yang terjadi secara alami. Proses penguraian dioptimalkan sedemikian rupa sehingga pengomposan dapat berjalan dengan lebih cepat dan efisien. Teknologi pengomposan saat ini menjadi sangat penting artinya terutama untuk mengatasi permasalahan limbah organik, seperti untuk mengatasi masalah sampah di kota-kota besar, limbah organik industry, serta limbah pertanian dan perkebunan.

Pengomposan secara aerobik paling banyak digunakan, karena mudah dan murah untuk dilakukan, serta tidak membutuhkan kontrol proses yang terlalu sulit. Dekomposisi bahan dilakukan oleh mikroorganisme di dalam bahan itu sendiri dengan bantuan udara. Sedangkan pengomposan secara anaerobik memanfaatkan mikroorganisme yang tidak membutuhkan udara dalam mendegradasi bahan organik. Hasil akhir dari pengomposan ini merupakan bahan yang sangat dibutuhkan untuk kepentingan tanah-tanah pertanian di Indonesia, sebagai upaya untuk memperbaiki sifat kimia, fisika dan biologi tanah, sehingga produksi tanaman menjadi lebih tinggi. Kompos yang dihasilkan dari pengomposan sampah dapat digunakan untuk menguatkan struktur lahan kritis, menggemburkan kembali tanah pertanian, menggemburkan kembali tanah petamanan, sebagai bahan penutup sampah di TPA, eklamasi pantai pasca penambangan, dan sebagai media tanaman.

Bahan baku pengomposan adalah semua material organik mengandung karbon dan nitrogen, seperti kotoran hewan, sampah hijauan, sampah kota, lumpur cair dan limbah industri pertanian. Berikut disajikan bahan-bahan yang umum dijadikan bahan baku pengomposan.

Tabel 1. Asal dan bahan kompos

\begin{tabular}{|l|l|}
\hline \multicolumn{1}{|c|}{ Asal } & \multicolumn{1}{c|}{ Bahan } \\
\hline 1. Pertanian & \multicolumn{1}{|c|}{} \\
\hline Limbah dan residu tanaman & $\begin{array}{l}\text { Jerami dan sekam padi, gulma, batang dan } \\
\text { tongkol jagung, semua bagian vegetatif } \\
\text { tanaman, batang pisang dan sabut kelapa }\end{array}$ \\
\hline Limbah \& residu ternak & $\begin{array}{l}\text { Kotoran padat, limbah ternak cair, limbah } \\
\text { pakan ternak, cairan biogas }\end{array}$ \\
\hline Tanaman air & $\begin{array}{l}\text { Azola, ganggang biru, enceng gondok, gulma } \\
\text { air }\end{array}$ \\
\hline 2. Industri & $\begin{array}{l}\text { Serbuk gergaji kayu, blotong, kertas, ampas } \\
\text { tebu, limbah kelapa sawit, limbah } \\
\text { pengalengan makanan dan pemotongan } \\
\text { hewan }\end{array}$ \\
\hline Limbah padat &
\end{tabular}




\begin{tabular}{|l|l|}
\hline Limbah cair & $\begin{array}{l}\text { Alkohol, limbah pengolahan kertas, } \\
\text { ajinomoto, limbah pengolahan minyak kelapa } \\
\text { sawit }\end{array}$ \\
\hline 3. Limbah rumah tangga & $\begin{array}{l}\text { Tinja, urin, sampah rumah tangga dan sampah } \\
\text { kota }\end{array}$ \\
\hline Sampah & \multicolumn{2}{|l}{} \\
\hline
\end{tabular}

(Sumber: Abdorohin dan Oim, 2008)

Kompos memperbaiki struktur tanah dengan meningkatkan kandungan bahan organik tanah dan akan meningkatkan kemampuan tanah untuk mempertahankan kandungan air tanah. Aktivitas mikroba tanah yang bermanfaat bagi tanaman akan meningkat dengan penambahan kompos. Aktivitas mikroba ini membantu tanaman untuk menyerap unsur hara dari tanah. Aktivitas mikroba tanah juga diketahui dapat membantu tanaman menghadapi serangan penyakit.

Tanaman yang dipupuk dengan kompos juga cenderung lebih baik kualitasnya daripada tanaman yang dipupuk dengan pupuk kimia, misal: hasil panen lebih tahan disimpan, lebih berat, lebih segar, dan lebih enak. Kompos memiliki banyak manfaat, antara lain: menghemat biaya untuk transportasi dan penimbunan limbah, mengurangi volume/ukuran limbah, memiliki nilai jual yang lebih tinggi dari pada bahan asalnya, mengurangi polusi udara karena pembakaran limbah dan pelepasan gas metana dari sampah organik yang membusuk akibat bakteri metanogen di tempat pembuangan sampah, mengurangi kebutuhan lahan untuk penimbunan, meningkatkan kesuburan tanah, memperbaiki struktur dan karakteristik tanah, meningkatkan kapasitas penyerapan air oleh tanah, meningkatkan aktivitas mikroba tanah, meningkatkan kualitas hasil panen (rasa, nilai gizi, dan jumlah panen), menyediakan hormon dan vitamin bagi tanaman, menekan pertumbuhan/serangan penyakit tanaman, dan meningkatkan retensi/ketersediaan hara di dalam tanah.

Pupuk kompos sebagai bahan organik sangat berperan terhadap sifat fisik tanah, antara lain: merangsang granulasi, memperbaiki aerasi tanah, dan meningkatkan kemampuan menahan air. Peran bahan organik terhadap sifat biologis tanah adalah meningkatkan aktivitas mikroorganisme yang berperan pada fiksasi nitrogen dan transfer hara tertentu seperti N, P, dan S. Peran bahan organik terhadap sifat kimia tanah adalah meningkatkan kapasitas tukar kation sehingga mempengaruhi serapan hara oleh tanaman (Gaur, 1980). 
Beberapa studi telah dilakukan terkait manfaat kompos bagi tanah dan pertumbuhan tanaman. Penelitian Abdurohim (2008) menunjukkan bahwa kompos memberikan peningkatan kadar Kalium pada tanah lebih tinggi dari pada kalium yang disediakan pupuk NPK, namun kadar fosfor tidak menunjukkan perbedaan yang nyata dengan NPK. Hal ini menyebabkan pertumbuhan tanaman yang ditelitinya ketika itu, caisin (Brassica oleracea), menjadi lebih baik dibandingkan dengan NPK. Hasil penelitian Handayani (2009) berdasarkan hasil uji Duncan, pupuk cacing (vermicompost) memberikan hasil pertumbuhan yang terbaik pada pertumbuhan bibit Salam (Eugenia polyantha Wight) pada media tanam subsoil. Indikatornya terdapat pada diameter batang, dan sebagainya. Hasil penelitian juga menunjukkan bahwa penambahan pupuk anorganik tidak memberikan efek apapun pada pertumbuhan bibit, mengingat media tanam subsoil merupakan media tanam dengan $\mathrm{pH}$ yang rendah sehingga penyerapan hara tidak optimal. Pemberian kompos akan menambah bahan organik tanah sehingga meningkatkan kapasitas tukar kation tanah dan mempengaruhi serapan hara oleh tanah, walau tanah dalam keadaan masam. Dalam sebuah artikel yang diterbitkan Departemen Agronomi dan Hortikultura, Institut Pertanian Bogor menyebutkan bahwa kompos bagase (kompos yang dibuat dari ampas tebu) yang diaplikasikan pada tanaman tebu (Saccharum officinarum L) meningkatkan penyerapan nitrogen secara signifikan setelah tiga bulan pengaplikasian dibandingkan degan yang tanpa kompos, namun tidak ada peningkatan yang berarti terhadap penyerapan fosfor, kalium, dan sulfur. Penggunaan kompos bagase dengan pupuk anorganik secara bersamaan tidak meningkatkan laju pertumbuhan, tinggi, dan diameter dari batang, namun diperkirakan dapat meningkatkan rendemen gula dalam tebu.

Pada dasarnya semua bahan-bahan organik padat dapat dikomposkan, misalnya: limbah organik rumah tangga, sampah-sampah organik pasar/kota, kertas, kotoran/limbah peternakan, limbah-limbah pertanian, limbah-limbah agroindustri, limbah pabrik kertas, limbah pabrik gula, limbah pabrik kelapa sawit, dan lain-lainya. Proses pengomposan akan segera berlansung setelah bahan-bahan mentah dicampur. Proses pengomposan secara sederhana dapat dibagi menjadi dua tahap, yaitu tahap aktif dan tahap pematangan. Selama tahap-tahap awal proses, oksigen dan senyawa-senyawa yang mudah terdegradasi akan segera dimanfaatkan oleh mikroba mesofilik. Suhu 
tumpukan kompos akan meningkat dengan cepat. Demikian pula akan diikuti dengan peningkatan $\mathrm{pH}$ kompos. Suhu akan meningkat hingga di atas $50^{\circ}-70^{\circ} \mathrm{C}$. Suhu akan tetap tinggi selama waktu tertentu. Mikroba yang aktif pada kondisi ini adalah mikroba Termofilik, yaitu mikroba yang aktif pada suhu tinggi. Pada saat ini terjadi dekomposisi/penguraian bahan organik yang sangat aktif. Mikroba-mikroba di dalam kompos dengan menggunakan oksigen akan menguraikan bahan organik menjadi $\mathrm{CO}_{2}$, uap air dan panas. Setelah sebagian besar bahan telah terurai, maka suhu akan berangsur-angsur mengalami penurunan. Pada saat ini terjadi pematangan kompos tingkat lanjut, yaitu pembentukan komplek liat humus. Selama proses pengomposan akan terjadi penyusutan volume maupun biomassa bahan. Pengurangan ini dapat mencapai $30-40 \%$ dari volume/bobot awal bahan.

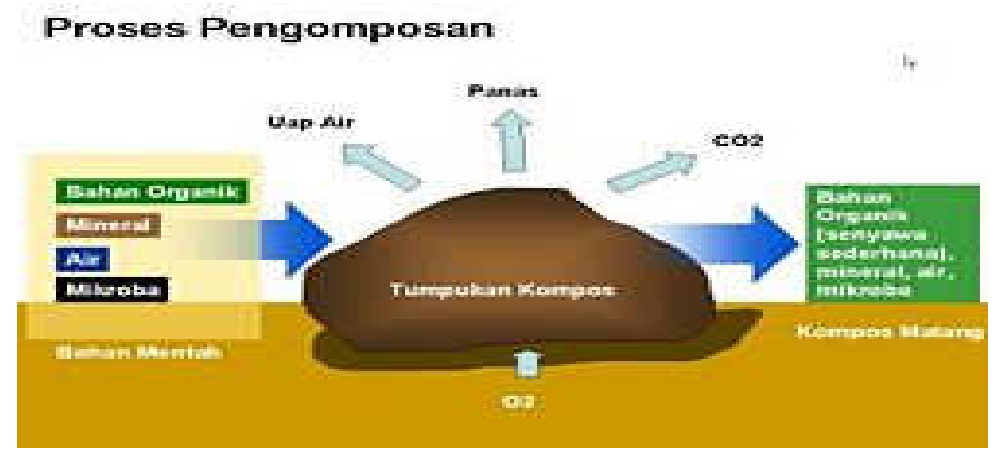

Gambar 1. Skema Proses Pengomposan Aerobik (Sumber: Rohendi, 2005)

Proses pengomposan dapat terjadi secara aerobik (menggunakan oksigen) atau anaerobik (tidak ada oksigen). Proses yang dijelaskan sebelumnya adalah proses aerobik, dimana mikroba menggunakan oksigen dalam proses dekomposisi bahan organik. Proses dekomposisi dapat juga terjadi tanpa menggunakan oksigen yang disebut proses anaerobik. Namun, proses ini tidak diinginkan, karena selama proses pengomposan akan dihasilkan bau yang tidak sedap. Proses anaerobik akan menghasilkan senyawa-senyawa yang berbau tidak sedap, seperti: asam-asam organik (asam asetat, asam butirat, asam valerat, puttrecine), amonia, dan $\mathrm{H}_{2} \mathrm{~S}$. 


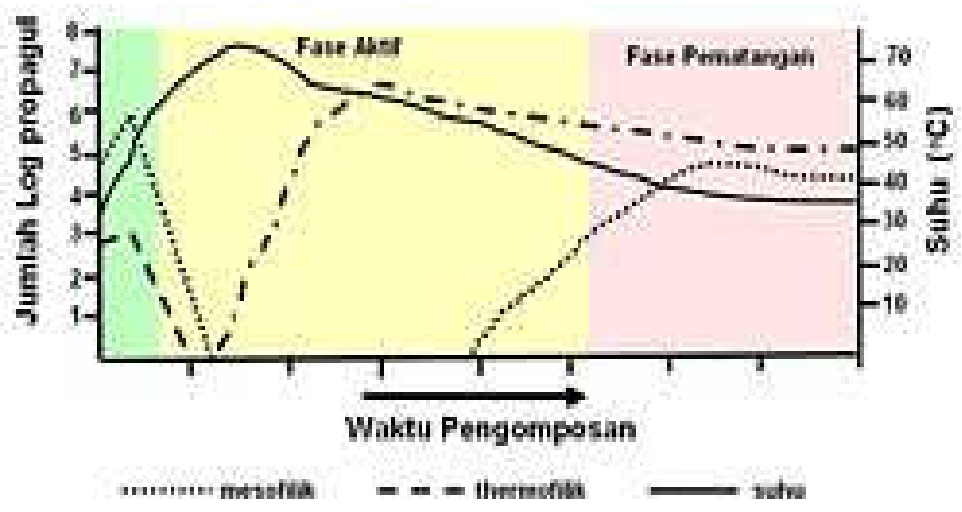

Gambar 2. Profil suhu dan populasi mikroba selama proses pengomposan (Sumber: Guntoro, dkk.,2003)

Tabel 2. Organisme yang terlibat dalam proses pengomposan

\begin{tabular}{|l|l|l|}
\hline Kelompok Organisme & \multicolumn{1}{c|}{ Organisme } & \multicolumn{1}{c|}{ Jumlah/gr kompos } \\
\hline Mikroflora & Bakteri; Aktinomicetes; Kapang & $10^{9}-10^{9} ; 10^{5} 10^{8} ; 10^{4}-10^{6}$ \\
\hline Mikrofanuna & Protozoa & $10^{4}-10^{5}$ \\
\hline Makroflora & Jamur tingkat tinggi & \\
\hline Makrofauna & Cacing tanah, rayap, semut, kutu, dll & \\
\hline
\end{tabular}

(Sumber: Toharisman, 1991)

Setiap organisme pendegradasi bahan organik membutuhkan kondisi lingkungan dan bahan yang berbeda-beda. Apabila kondisinya sesuai, maka dekomposer tersebut akan bekerja giat untuk mendekomposisi limbah padat organik. Apabila kondisinya kurang sesuai atau tidak sesuai, maka organisme tersebut akan dorman, pindah ke tempat lain, atau bahkan mati. Menciptakan kondisi yang optimum untuk proses pengomposan sangat menentukan keberhasilan proses pengomposan itu sendiri.

Faktor-faktor yang memperngaruhi proses pengomposan antara lain:

\section{Rasio $\mathrm{C} / \mathrm{N}$}

Rasio C/N yang efektif untuk proses pengomposan berkisar antara 30: 1 hingga 40:1. Mikroba memecah senyawa $\mathrm{C}$ sebagai sumber energi dan menggunakan $\mathrm{N}$ untuk sintesis protein. Pada rasio $\mathrm{C} / \mathrm{N}$ di antara 30 s/d 40 mikroba mendapatkan cukup C untuk energi dan $\mathrm{N}$ untuk sintesis protein. Apabila rasio $\mathrm{C} / \mathrm{N}$ terlalu tinggi, mikroba akan kekurangan $\mathrm{N}$ untuk sintesis protein sehingga dekomposisi berjalan lambat.

Umumnya, masalah utama pengomposan adalah pada rasio $\mathrm{C} / \mathrm{N}$ yang tinggi, terutama jika bahan utamanya adalah bahan yang mengandung kadar kayu tinggi (sisa gergajian 
kayu, ranting, ampas tebu, dsb). Untuk menurunkan rasio $\mathrm{C} / \mathrm{N}$ diperlukan perlakuan khusus, misalnya menambahkan mikroorganisme selulotik (Toharisman, 1991) atau dengan menambahkan kotoran hewan karena kotoran hewan mengandung banyak senyawa nitrogen.

\section{Ukuran Partikel}

Aktivitas mikroba berada diantara permukaan area dan udara. Permukaan area yang lebih luas akan meningkatkan kontak antara mikroba dengan bahan dan proses dekomposisi akan berjalan lebih cepat. Ukuran partikel juga menentukan besarnya ruang antar bahan (porositas). Untuk meningkatkan luas permukaan dapat dilakukan dengan memperkecil ukuran partikel bahan tersebut.

3. Aerasi

Pengomposan yang cepat dapat terjadi dalam kondisi yang cukup oksigen(aerob). Aerasi secara alami akan terjadi pada saat terjadi peningkatan suhu yang menyebabkan udara hangat keluar dan udara yang lebih dingin masuk ke dalam tumpukan kompos. Aerasi ditentukan oleh posiritas dan kandungan air bahan(kelembaban). Apabila aerasi terhambat, maka akan terjadi proses anaerob yang akan menghasilkan bau yang tidak sedap. Aerasi dapat ditingkatkan dengan melakukan pembalikan atau mengalirkan udara di dalam tumpukan kompos.

\section{Porositas}

Porositas adalah ruang diantara partikel di dalam tumpukan kompos. Porositas dihitung dengan mengukur volume rongga dibagi dengan volume total. Rongga-rongga ini akan diisi oleh air dan udara. Udara akan mensuplay Oksigen untuk proses pengomposan. Apabila rongga dijenuhi oleh air, maka pasokan oksigen akan berkurang dan proses pengomposan juga akan terganggu.

\section{Kelembaban (Moisture content)}

Kelembaban memegang peranan yang sangat penting dalam proses metabolisme mikroba dan secara tidak langsung berpengaruh pada suplay oksigen. Mikrooranisme dapat memanfaatkan bahan organik apabila bahan organik tersebut larut di dalam air. Kelembaban 40 - $60 \%$ adalah kisaran optimum untuk metabolisme mikroba. Apabila kelembaban di bawah $40 \%$, aktivitas mikroba akan mengalami penurunan dan akan lebih rendah lagi pada kelembaban 15\%. Apabila kelembaban lebih besar dari $60 \%$, 
hara akan tercuci, volume udara berkurang, akibatnya aktivitas mikroba akan menurun dan akan terjadi fermentasi anaerobik yang menimbulkan bau tidak sedap.

6. Temperatur/suhu

Panas dihasilkan dari aktivitas mikroba. Ada hubungan langsung antara peningkatan suhu dengan konsumsi oksigen. Semakin tinggi temperatur akan semakin banyak konsumsi oksigen dan akan semakin cepat pula proses dekomposisi. Peningkatan suhu dapat terjadi dengan cepat pada tumpukan kompos. Temperatur yang berkisar antara 30 - 60oC menunjukkan aktivitas pengomposan yang cepat. Suhu yang lebih tinggi dari $60 \mathrm{oC}$ akan membunuh sebagian mikroba dan hanya mikroba thermofilik saja yang akan tetap bertahan hidup. Suhu yang tinggi juga akan membunuh mikroba-mikroba patogen tanaman dan benih-benih gulma.

7. $\mathrm{pH}$

Proses pengomposan dapat terjadi pada kisaran $\mathrm{pH}$ yang lebar. $\mathrm{pH}$ yang optimum untuk proses pengomposan berkisar antara 6.5 sampai 7.5. $\mathrm{pH}$ kotoran ternak umumnya berkisar antara 6.8 hingga 7.4. Proses pengomposan sendiri akan menyebabkan perubahan pada bahan organik dan $\mathrm{pH}$ bahan itu sendiri. Sebagai contoh, proses pelepasan asam, secara temporer atau lokal, akan menyebabkan penurunan $\mathrm{pH}$ (pengasaman), sedangkan produksi amonia dari senyawa-senyawa yang mengandung nitrogen akan meningkatkan $\mathrm{pH}$ pada fase-fase awal pengomposan. $\mathrm{pH}$ kompos yang sudah matang biasanya mendekati netral.

8. Kandungan Hara

Kandungan $\mathrm{P}$ dan $\mathrm{K}$ juga penting dalam proses pengomposan dan bisanya terdapat di dalam kompos-kompos dari peternakan. Hara ini akan dimanfaatkan oleh mikroba selama proses pengomposan.

\section{Kandungan Bahan Berbahaya}

Beberapa bahan organik mungkin mengandung bahan-bahan yang berbahaya bagi kehidupan mikroba. Logam-logam berat seperti $\mathrm{Mg}, \mathrm{Cu}, \mathrm{Zn}$, Nickel, $\mathrm{Cr}$ adalah beberapa bahan yang termasuk kategori ini. Logam-logam berat akan mengalami imobilisasi selama proses pengomposan. 
10. Lama pengomposan

Lama waktu pengomposan tergantung pada karakteristik bahan yang dikomposakan, metode pengomposan yang dipergunakan dan dengan atau tanpa penambahan aktivator pengomposan. Secara alami pengomposan akan berlangsung dalam waktu beberapa minggu sampai 2 tahun hingga kompos benar-benar matang.

Tabel 3. Kondisi yang optimal untuk mempercepat proses pengomposan

\begin{tabular}{|l|l|l|}
\hline \multicolumn{1}{|c|}{ Kondisi } & Konsisi yang bisa diterima & \multicolumn{1}{c|}{ Ideal } \\
\hline Rasio C/N & $20: 1 \mathrm{~s} / \mathrm{d} 40: 1$ & $25-35: 1$ \\
\hline Kelembaban & $40-65 \%$ & $45-62 \%$ berat \\
\hline Konsentrasi oksigen tersedia & $>5 \%$ & $>10 \%$ \\
\hline Ukuran partikel & 1 inchi & Bervariasi \\
\hline Bulk Density & $1000 \mathrm{lbs} / \mathrm{cu}$ yd & $1000 \mathrm{lbs} / \mathrm{cu}$ yd \\
\hline pH & $5.5-9.0$ & $6.5-8.0$ \\
\hline Suhu & $43-66 \circ \mathrm{C}$ & $54-60 \mathrm{oC}$ \\
\hline
\end{tabular}

(Sumber: Gaur, 1980)

Strategi pengomposan banyak dilakukan di awal-awal berkembangnya teknologi pengomposan. Kondisi atau faktor-faktor pengomposan dibuat seoptimum mungkin. Sebagai contoh, rasio C/N yang optimum adalah 25-35:1. Untuk membuat kondisi ini bahan-bahan yang mengandung rasio $\mathrm{C} / \mathrm{N}$ tinggi dicampur dengan bahan yang mengandung rasio $\mathrm{C} / \mathrm{N}$ rendah, seperti kotoran ternak. Ukuran bahan yang besar-besar dicacah sehingga ukurannya cukup kecil dan ideal untuk proses pengomposan. Bahan yang terlalu kering diberi tambahan air atau bahan yang terlalu basah dikeringkan terlebih dahulu sebelum proses pengomposan.

Pengomposan secara aerobik

Peralatan yang dibutuhkan dalam pengomposan secara aerobik terdiri dari peralatan untuk penanganan bahan dan peralatan perlindungan keselamatan dan kesehatan bagi pekerja. Berikut disajikan peralatan yang digunakan.

1. Terowongan udara (Saluran Udara)

- Digunakan sebagai dasar tumpukan dan saluran udara

- Terbuat dari bambu dan rangka penguat dari kayu

- Dimensi : panjang $2 \mathrm{~m}$, lebar $1 / 4-1 / 2 \mathrm{~m}$, tinggi $1 / 2 \mathrm{~m}$ 
- Sudut : 45o

- Dapat dipakai menahan bahan $2-3$ ton

2. Sekop

- Alat bantu dalam pengayakan dan tugas-tugas lainnya

3. Garpu/cangkrang

- Digunakan untuk membantu proses pembalikan tumpukan bahan dan pemilahan sampah

4. Saringan/ayakan

- Digunakan untuk mengayak kompos yang sudah matang agar diperoleh ukuran yang sesuai

- Ukuran lubang saringan disesuaikan dengan ukuran kompos yang diinginkan

- Saringan bisa berbentuk papan saring yang dimiringkan atau saringan putar

5. Termometer

- Digunakan untuk mengukur suhu tumpukan

- Pada bagian ujungnya dipasang tali untuk mengulur termometer ke bagian dalam tumpukan dan menariknya kembali dengan cepat

- Sebaiknya digunakan termometer alkohol (bukan air raksa) agar tidak mencemari kompos jika termometer pecah

6. Timbangan

- Digunakan untuk mengukur kompos yang akan dikemas sesuai berat yang diinginkan

- Jenis timbangan dapat disesuaikan dengan kebutuhan penimbangan dan pengemasan

7. Sepatu boot

- Digunakan oleh pekerja untuk melindungi kaki selama bekerja agar terhindar dari bahan-bahan berbahaya

8. Sarung tangan 
- Digunakan oleh pekerja untuk melindungi tangan selama melakukan pemilahan bahan dan untuk kegiatan lain yang memerlukan perlindungan tangan

9. Masker

- Digunakan oleh pekerja untuk melindungi pernafasan dari debu dan gas bahan terbang lainnya

\section{Tahapan pengomposan}

1. Pemilahan Sampah

- Pada tahap ini dilakukan pemisahan sampah organik dari sampah anorganik (barang lapak dan barang berbahaya). Pemilahan harus dilakukan dengan teliti karena akan menentukan kelancaran proses dan mutu kompos yang dihasilkan

2. Pengecil Ukuran

- Pengecil ukuran dilakukan untuk memperluas permukaan sampah, sehingga sampah dapat dengan mudah dan cepat didekomposisi menjadi kompos

3. Penyusunan Tumpukan

- Bahan organik yang telah melewati tahap pemilahan dan pengecil ukuran kemudian disusun menjadi tumpukan.

- Desain penumpukan yang biasa digunakan adalah desain memanjang dengan dimensi panjang $\mathrm{x}$ lebar $\mathrm{x}$ tinggi $=2 \mathrm{~m} \times 12 \mathrm{~m} \times 1,75 \mathrm{~m}$.

- Pada tiap tumpukan dapat diberi terowongan bambu (windrow) yang berfungsi mengalirkan udara di dalam tumpukan.

4. Pembalikan

- Pembalikan dilakuan untuk membuang panas yang berlebihan, memasukkan udara segar ke dalam tumpukan bahan, meratakan proses pelapukan di setiap bagian tumpukan, meratakan pemberian air, serta membantu penghancuran bahan menjadi partikel kecil-kecil.

5. Penyiraman

- Pembalikan dilakukan terhadap bahan baku dan tumpukan yang terlalu kering (kelembaban kurang dari 50\%). 
- Secara manual perlu tidaknya penyiraman dapat dilakukan dengan memeras segenggam bahan dari bagian dalam tumpukan.

- Apabila pada saat digenggam kemudian diperas tidak keluar air, maka tumpukan sampah harus ditambahkan air. sedangkan jika sebelum diperas sudah keluar air, maka tumpukan terlalu basah oleh karena itu perlu dilakukan pembalikan.

6. Pematangan

- Setelah pengomposan berjalan 30 - 40 hari, suhu tumpukan akan semakin menurun hingga mendekati suhu ruangan.

- Pada saat itu tumpukan telah lapuk, berwarna coklat tua atau kehitaman. Kompos masuk pada tahap pematangan selama 14 hari.

7. Penyaringan

- Penyaringan dilakukan untuk memperoleh ukuran partikel kompos sesuai dengan kebutuhan serta untuk memisahkan bahan-bahan yang tidak dapat dikomposkan yang lolos dari proses pemilahan di awal proses.

- Bahan yang belum terkomposkan dikembalikan ke dalam tumpukan yang baru, sedangkan bahan yang tidak terkomposkan dibuang sebagai residu.

8. Pengemasan dan Penyimpanan

- Kompos yang telah disaring dikemas dalam kantung sesuai dengan kebutuhan pemasaran.

- Kompos yang telah dikemas disimpan dalam gudang yang aman dan terlindung dari kemungkinan tumbuhnya jamur dan tercemari oleh bibit jamur dan benih gulma dan benih lain yang tidak diinginkan yang mungkin terbawa oleh angin.

Mutu kompos

Komposyang baik adalah.

1. Kompos yang bermutu adalah kompos yang telah terdekomposisi dengan sempurna serta tidak menimbulkan efek-efek merugikan bagi pertumbuhan tanaman. 
2. Penggunaan kompos yang belum matang akan menyebabkan terjadinya persaingan bahan nutrien antara tanaman dengan mikroorganisme tanah yang mengakibatkan terhambatnya pertumbuhan tanaman

3. Kompos yang baik memiliki beberapa ciri sebagai berikut :

- Berwarna coklat tua hingga hitam mirip dengan warna tanah,

- Tidak larut dalam air, meski sebagian kompos dapat membentuk suspensi,

- Nisbah $\mathrm{C} / \mathrm{N}$ sebesar 10 - 20, tergantung dari bahan baku dan derajat humifikasinya,

- Berefek baik jika diaplikasikan pada tanah,

- Suhunya kurang lebih sama dengan suhu lingkungan, dan

Tidak berbau.

\section{Metode Pelaksanaan Pengabdian}

Metode yang digunakan untuk memecahkan masalah di atas adalah metode diskusi dan praktek. Gabungan dari kedua metode tersebut diharapkan meningkatkan keterampilan membuat pupuk kompos dari limbah pertanian serta menerapkannya dan meningkatkan pemahaman terhadap penggunaan pupuk kompos dari limbah pertanian. Dengan demikian dapat mengurangi ketergantukan para petani padi di Subak Telaga Desa Mas terhadap pupuk urea sehingga tidak terpengaruh terhadap harga pupuk yang mahal dan produksi padi.

\section{Hasil dan Pembahasan}

Para petani di Subak Telaga Desa Mas Ubud telah mengenal pupuk kompos, tetapi cara membuat, waktu penggunaan, dan takaran penggunaan kompos belum dipahami untuk tanaman padi. Para petani sangat antusias untuk mengetahui cara membuat kompos dari jerami. Berdasarkan cara pembuatan kompos, para petani lebih tertarik menggunakan cara ke-3, yaitu menebar jerami dipematang sawah kemudian dibasahi dan disemprotkan bakteri pengurai. Cara ini dipilih oleh petani didasari pada kepraktisannya, karena para petani di subak telaga memiliki ketrampilan lain, yaitu sebagai tukang bangunan, pematung, dan pegawai negeri. 
Antosiasme para petani mengikuti kegiatan, terlihat dari banyak pertanyaan yang diajukan oleh para petani. Jenis pertanyaan yang muncul adalah: selain jerami, bahan apa yang bisa digunakan sebagai kompos?, syarat-syarat agar kompos dapat bekerja maksimal?, tindakan yang dapat dilakukan untuk memepercepat pengomposan? Pertanyaan-pertanyaan tersebut mengindikasikan bahwa ketertarikan petani untuk membuat kompos dan memakainya. Indikasi lain yang menunjukkan ketertarikan petani terhadap pelatihan ini adalah jumlah pesanan mikrobia yang digunakan untuk membuat kompos. Semua peserta memesan mikrobia untuk digunakan membuat kompos, dan sebagai pupuk cair.

Pengetahuan para peserta tentang keunggulan kompos dibandingkan pupuk anorganik (urea) telah mulai berkembang. Indikasi tersebut terlihat dari rencana mereka untuk mengurangi pemakaian pupuk urea. Bahkan para petani sudah mulai menggunakan pupuk kompos dengan memesan kompos pada nara sumber rata-rata 40 Kg. Untuk mencapai hasil yang maksimal, maka pemakaian kompos dengan menggunakan probiotik harus mengurangi penggunaan herbisida, fungisida, dan bahan kimia yang lainnya.

Keunggulan penggunaan pupuk kompos telah dirasakan oleh para petani. Keunggulan tersebut dilihat dari kegemburan tanah, kemudahan mencanggkul, mulai ditemukan kehidupan di sawah (belut, cacing, dan sebagainya). Penampakan kehidupan hewan tersebut menambah semangat para petani untuk membuat kompos dan menggunakannya. Ketercapaian kegiatan, indicator dan cara pengukuran dapat dilihat dalam Tabel 4.

Tabel 4 Ketercapaian kegiatan dan indikator

\begin{tabular}{|l|l|l|}
\hline No & \multicolumn{1}{|c|}{ Indikator } & \multicolumn{1}{c|}{ Ketercapaian } \\
\hline 1 & $\begin{array}{l}\text { Petani mengetahui dampak } \\
\text { buruk pemakaian pupuk } \\
\text { urea secara terus menerus }\end{array}$ & $\begin{array}{l}\text { Petani mengetahui keunggulan kompos } \\
\text { dan kelemahan pupuk anorganik (urea dsb) }\end{array}$ \\
\hline 2 & $\begin{array}{l}\text { Petani dapat memanfaatkan } \\
\text { jerami }\end{array}$ & $\begin{array}{l}\text { Jerami mulai tidak dibakar tapi } \\
\text { ditempatkan pada lahan lain }\end{array}$ \\
\hline 3 & $\begin{array}{l}\text { Petani memakai pupuk } \\
\text { kompos }\end{array}$ & $\begin{array}{l}\text { Petani mulai memakai kompos maksimal } \\
\text { 40 kg per garapan sawah }\end{array}$ \\
\hline 4 & $\begin{array}{l}\text { Petani dapat membuat } \\
\text { kompos dari jerami padi dan }\end{array}$ & $\begin{array}{l}\text { Petani dapat membuat pupuk kompos dari } \\
\text { jerami }\end{array}$ \\
\hline
\end{tabular}




\begin{tabular}{|l|l|l|}
\hline & kotoran sapi & \\
\hline 5 & $\begin{array}{l}\text { Dapat menggunakan } \\
\text { kompos jerami padi dengan } \\
\text { benar }\end{array}$ & $\begin{array}{l}\text { Petani telah mengetahui cara penggunaan } \\
\text { pupuk kompos berprobiotik dengan } \\
\text { mengurangi penggunaan herbisida, } \\
\text { insektisida }\end{array}$ \\
\hline 6 & $\begin{array}{l}\text { Dapat membandingkan, } \\
\text { tanah, jenis binatang yang } \\
\text { hidup di sawah, dan } \\
\text { tanamam padi yang diberi } \\
\text { pupuk urea dengan kompos }\end{array}$ & $\begin{array}{l}\text { Petani telah dapat membedakan kualitas } \\
\text { tanah dengan menggunakan kompos } \\
\text { dengan indikasi: tanah tidak liat (gampang } \\
\text { dicangkul), mulai ada belut dan ikan hidup } \\
\text { di sawah }\end{array}$ \\
\hline
\end{tabular}

Pengetahuan para petani di Subak Telaga tentang kompos sangat beragam. Akan tetapi ketertarikan mereka sangat tinggi untuk menggunakan kompos. Hal ini merupakan suatu langkah bagus untuk merubah ketergantungan para petani terhadap pupuk anorganik, seperti urea, TSP dan lain-lain. Pelatihan pembuatan kompos adalah salah satu upaya untuk meningkatkan kemampuan petani agar tidak tergantung pada pupuk urea, tsp dan sejenisnya.

Pengurangan penggunaan urea dan sejenisnya oleh petani dengan memproduksi kompos sendiri merupakan suatu langkah penghematan biaya produksi. Penghematan biaya produksi tersebut akan dapat menambah pendapat para petani di Subak Telaga dan pada akhirnya dapat lebih mensejahterakannya. Pelatihan pembuatan kompos di Subak Telaga merupakan suatu langkah awal untuk membangun pertanian, khususnya padi menuju pertanian organik yang ramah lingkungan. Hal tersebut telah dirasakan oleh para petani di Subak Telaga. Indikasi yang telah dirasakan adalah cacing tanah di tanah mulai bermunculan, tanah gampang dicangkul, tanah mulai gembur, mulai ada berudu diperaian sawah, dan terdapat kehidupan hewan lainnya.

Dampak positip kompos yang telah dirasakan para petani di Subak Telaga tentu sangat bermanfaat agar tanah sawah tidah dialihfungsikan menjadi bangunan beton yang mendesak daerah pertanian di Subak Telaga. Disisi lain, kebutuhan akan beras sebagai makanan pokok masih sebagai andalan. Pelatihan pembuatan kompos merupakan salah satu upaya secara tidak langsung untuk mempertahankan sawah-sawah yang mulai terdesak di Desa Mas. 


\section{Penutup}

Berdasarkan uraian pembahasan, dapat disimpulkan para petani padi Subak Telaga Desa Mas Ubud: a)semakin mengurangi penggunaan pupuk urea dan perlahan-lahan mengganti dengan kompos, b)semakin mengerti terhadap dampak negative akibat pemakaian pupuk urea secara terus-menerus, c) telah mampu mebuat pupuk kompos dari limbah pertanian, dan d) telah mengetahui cara menggunakan kompos yang benar. Pelatihan ini sangat dirasakan oleh para petani, untuk itu petani sangat mengharapkan terus diadakan pelatihan yang dapat meningkatkan hasil pertanian dan teknik pengolahannya. Petani sangat mengharapkan pelatihan yang dapat memasarkan produkproduk pertanian yang layak.

\section{DAFTAR PUSTAKA}

Abdurohim, Oim. 2008. Pengaruh Kompos Terhadap Ketersediaan Hara Dan Produksi Tanaman Caisin Pada Tanah Latosol Dari Gunung Sindur, sebuah skripsi. Dalam IPB Information Resource Center, diunduh 13 Juni 2010.

Budi Hartoyo, 2010. Pengelolaan Unsur Hara P Dan K Padi Sawah Di Lahan Irigasi. Jawa Tengah: Balai Pengkajian Teknologi Pertanian Jawa Tengah

Daniel Suryoputro. 2009. Pemberian Pupuk Berimbang untuk Mengoptimalkan Hasil Gabah pada Pertanaman Padi. http://perpadi.or.id/index.php? option=com content\&view=article\&id=53: pemberian-pupuk-berimbang-untukmengoptimalkan -hasil-gabah-pada-pertanam. Dikunjungi 7 Desember 2010.

Gaur, D. C. 1980. Present Status of Composting and Agricultural Aspect, in: Hesse, P. R. (ed). Improvig Soil Fertility Through Organic Recycling, Compost Technology. FAO of United Nation. New Delhi.

Guntoro Dwi, Purwono, dan Sarwono. 2003. Pengaruh Pemberian Kompos Bagase Terhadap Serapan Hara Dan Pertumbuhan Tanaman Tebu (Saccharum officinarum L.). Dalam Buletin Agronomi, Departemen Agronomi dan Hortikultura, Institut Pertanian Bogor.

Handayani, Mutia. 2009. Pengaruh Dosis Pupuk NPK dan Kompos Terhadap Pertumbuhan Bibit Salam, sebuah skripsi. Dalam IPB Information Resource Center diunduh 13 Juni 2010.

Isroi. 2008. KOMPOS. Makalah. Balai Penelitian Bioteknologi Perkebunan Indonesia, Bogor.

Isroi. 2009. Hasil Analisa Kompos Jerami dan Nilai Haranya. http://isroi. wordpress. com/tag/promi/. Dikunjungi 2 Desember 2010.

Rohendi, E. 2005. Lokakarya Sehari Pengelolaan Sampah Pasar DKI Jakarta, sebuah prosiding. Bogor, 17 Februari 2005. 
Sonson Garsoni. 2010. Pupuk Padi, Pupuk Organik, Komposter Olah Limbah. http://undangjaya.indonetwork.co.id. Dikunjungi 20 Desember 2010

Toharisman, A. 1991. Potensi Dan Pemanfaatan Limbah Industri Gula Sebagai Sumber Bahan Organik Tanah.

Peter Tandisau dan Idaryani. 2010. Efektivitas penggunaan pupuk SP-36 dan KCL pada tanaman padi dan jagung. Sulawesi Selatan : Balai Pengkajian Teknologi Pertanian ( BPTP ). 